\title{
An Unusual Presentation of Varicella Meningitis: A Case Report and Review of the Literature
}

Matthew Patel, Rachel Bierbrier, BHSc, Katina Tzanetos, MD MSc

\author{
About the Authors \\ Matthew Patel is an Undergraduate Medical Student at the Royal College of Surgeons in Ireland. \\ Rachel Bierbrier is with the Department of Dermatology, McGill University Health Centre, Montreal. \\ Katina Tzanetos is with the Department of Medicine, University of Toronto \\ Submitted: August 25, 2018. Accepted: January 14, 2019. Published: November X, 2019.
}

\begin{abstract}
Varicella zoster virus (VZV) primary infection causes chickenpox, often in young children, and is characterized by vesicular lesions on the face, limbs, and trunk. In immunocompetent hosts, the infection is usually mild and self-limited. Following infection, the virus remains dormant in the dorsal root ganglia but can reactivate, replicate and cause herpes zoster (shingles), This report describes a case of reactivation VZV meningitis without any viral exanthema in a young healthy male.

\section{Résumé}

L'infection primaire par le virus varicelle-zona (VZV) cause la varicelle, souvent chez les jeunes enfants, et se caractérise par des lésions vésiculaires au visage, aux membres et au tronc. Chez les hôtes immunocompétents, l'infection est généralement légère et auto-limitée. Après l'infection, le virus reste dormant dans les ganglions rachidiens, mais il peut se réactiver, se répliquer et causer le zona (zona). Ce rapport décrit un cas de réactivation de la méningite à VZV sans exanthème viral chez un jeune homme sain.
\end{abstract}

Varicella zoster virus (VZV) primary infection causes chickenpox, often in young children, and is characterized by vesicular lesions on the face, limbs, and trunk. In immunocompetent hosts, the infection is usually mild and self-limited. Following infection, the virus remains dormant in the dorsal root ganglia but can reactivate, replicate and cause herpes zoster (shingles), a painful vesicular eruption in a single dermatomal distribution. ${ }^{1,2}$ Although herpes zoster typically presents with this characteristic rash, there are reports of zoster sine herpete herpes zoster without the presence of a rash but with pain. ${ }^{1}$ Neurologic complications, including meningitis, encephalitis or myelitis can occur with acute infection or reactivation of VZV, but is uncommon in immunocompetent hosts, and even more rare without an exanthema. ${ }^{3}$ This report describes a case of reactivation VZV meningitis without any viral exanthema in a young healthy male.

\section{Case Report}

A 19-year-old male attended the Emergency Department with a 6-day history of fever, worsening headache and neck stiffness. The headache increased with head movement and was unresponsive to analgesics. There was no preceding viral illness and he had no sick contacts. In the 2 days before presentation, he developed night sweats, myalgias and nausea, and vomiting. There was no rash, vision changes, focal neurological deficits, confusion 
or personality changes. While camping one week before the onset of headaches he had suffered multiple mosquito bites, but no tick bites. There was no history of oral or genital herpes simplex virus (HSV) lesions. He was in a stable, monogamous, heterosexual relationship for the past three years.

The patient reported that he did have chickenpox as a child. There was no medical or surgical history and all his vaccinations were up to date. He took no medications, smoked a half package of cigarettes daily for the past two years and consumed 4 to 6 alcoholic beverages weekly. There was no history of recreational drug use.

On examination, he was alert and oriented with normal vital signs and was afebrile. His neck was stiff and jolt accentuation was positive. Kernig's and Brudzinksi's signs were negative. There were no focal neurological abnormalities or skin rash. The remainder of the examination was unremarkable.

His laboratory data showed: white blood cell count (WBC) 9.2 with a normal differential cell count. A venous gas, electrolytes, renal and liver tests, chest radiography and noncontrast computed tomography of the brain were all normal. Plasma serology for syphilis and HIV was negative. A lumbar puncture was performed and the cerebrovascular fluid results are shown in Table 1.

The patient was treated with intravenous (IV) acyclovir and discharged 3 days later when his symptoms resolved. The

Table 1. Cerebrovascular Fluid Results

\begin{tabular}{|l|l|}
\hline \multicolumn{1}{|c|}{ CSF } & \multicolumn{1}{c|}{ Result } \\
\hline White Blood Cell Count & $\begin{array}{l}836(0-5 \times 106 / \mathrm{L}) 95 \% \\
\text { lymphocytes }\end{array}$ \\
\hline Red Blood Cell Count & $30(0-5 \times 106 / \mathrm{L})$ \\
\hline Xanthochromia & Absent \\
\hline Colour \& Clarity & Clear \& Colourless \\
\hline Glucose & $3.2 \mathrm{mmol} / \mathrm{L}(2.2-3.9)$ \\
\hline Protein & $0.90 \mathrm{~g} / \mathrm{L}$ (less than 0.45) \\
\hline Gram Stain \& Culture & Negative \\
\hline $\begin{array}{l}\text { PCR for West Nile, Enterovirus and } \\
\text { Herpes Simplex Virus I and II }\end{array}$ & Negative \\
\hline $\begin{array}{l}\text { PCR for Herpes Varicella Zoster } \\
\text { Virus }\end{array}$ & Positive \\
\hline
\end{tabular}

CFS = cerebrovascular fluid; $\mathrm{PCR}=$ polymerase chain reaction.
IV acyclovir was continued for a total of 14 days. The patient returned completely to his usual state of health.

\section{Discussion}

VZV is a member of the herpes-virus family. The virus is transmitted through respiratory droplets or direct contact with fluid from vesicular skin lesions. Chickenpox results from a primary VZV infection and is characterized by a typical vesicular rash that starts on the trunk and spreads to the face and extremities. After inoculation, the virus remains dormant in the sensory dorsal root ganglion and may reactivate to cause herpes zoster (shingles): a painful vesicular unilateral rash with a dermatomal distribution.

VZV infection will result in at least one complication in approximately $12 \%$ of individuals. ${ }^{4}$ Herpes zoster (shingles) is the most common complication of VZV reactivation and the most common complication of shingles is post-herpetic neuralgia (PHN); a severe neuropathic pain persisting for more than 4 months after the acute rash. ${ }^{5}$ Secondary bacterial infections are not uncommon. More rarely infection with VZV may cause vasculitis. Ischemic and hemorrhagic strokes, due to viral infection in cerebral arteries, are described. ${ }^{6}$ Neurologic complications including meningitis, encephalitis, transverse myelitis and Guillian-Barre syndrome are very rare but have been reported. ${ }^{1,6}$

Central nervous system (CNS) infection complicating shingles with a rash in young immunocompetent adults is recognized but unusual. Even rarer are CNS infections with VZV in young immunocompetent patients without a rash. ${ }^{7}$ This report describes a case of VZV meningitis in a young healthy man without any rash. The clinical presentation and physical exam findings were consistent with meningitis but not encephalitis. The cerebral spinal fluid (CSF) findings of increased protein and white blood cell counts with lymphocytic predominance supported a diagnosis of viral meningitis (Table 2). VZV polymerase chain reaction (PCR) was positive confirming VZV meningitis.

VZV meningitis and encephalitis more commonly occur in immunocompromised hosts but are increasingly recognized in immunocompetent hosts. This may reflect the newly easily available, broad-spectrum PCR testing that allows for diagnostic confirmation rather than a true change in incidence. Although uncommon, especially in the absence of the typical shingles rash, VZV must be considered in the differential diagnosis for clinically suspected CNS infections. Complete CSF fluid analysis, including PCR testing, is paramount to confirm the diagnosis.

Empiric therapy with broad-spectrum antibiotics and acyclovir at doses suitable for meningitis is recommended for

(continued) 
Table 2. The Cerebral Spinal Fluid (CSF) Findings Supporting a Diagnosis of Viral Meningitis

\begin{tabular}{|c|c|c|}
\hline Characteristic & Meningitis & Encephalitis \\
\hline Inflammation & Inflammation of the meninges & Inflammation of the brain parenchyma \\
\hline Clinical Features & $\begin{array}{l}\text { Fever } \\
\text { Headache } \\
\text { Vomiting } \\
\text { Photophobia } \\
\text { Irritability } \\
\text { Confusion } \\
\text { Nuchal rigidity } \\
\text { Opisthotonus } \\
\text { Purpuric non-blanching rash }\end{array}$ & $\begin{array}{l}\text { Seizures } \\
\text { Confusion } \\
\text { Attention deficits } \\
\text { Altered judgment } \\
\text { Motor or sensory deficits } \\
\text { Behaviour or personality changes } \\
\text { Speech disorders } \\
\text { Movement disorders }\end{array}$ \\
\hline Clinical Sequelae & $\begin{array}{l}\text { Hearing loss } \\
\text { Recurrent seizures } \\
\text { Problems with memory and concentration } \\
\text { Problems with coordination, balance, movement, behaviour } \\
\text { Vision loss } \\
\text { Loss of limbs } \\
\text { Bone + joint problems } \\
\text { Kidney problems } \\
\text { Learning difficulties } \\
\text { Cerebral palsy } \\
\text { Endotoxin shock } \\
\text { DIC }\end{array}$ & $\begin{array}{l}\text { Persistent fatigue } \\
\text { Weakness } \\
\text { Problems with balance, co-ordination and movement } \\
\text { Physical and motor difficulties } \\
\text { Paralysis } \\
\text { Memory problems } \\
\text { Hearing or vision defects } \\
\text { Personality and behavioural changes } \\
\text { Problems with attention, concentrating, planning and problem } \\
\text { solving } \\
\text { Swallowing problems } \\
\text { Aphasia speech and language problems } \\
\text { Intellectual disability } \\
\text { Coma } \\
\text { Difficulty breathing } \\
\text { Death }\end{array}$ \\
\hline \multicolumn{3}{|l|}{ Aetiology } \\
\hline \multirow[t]{2}{*}{ Cause } & $\begin{array}{l}\text { Viral: Enteroviruses, HSV, mumps } \\
\text { Most common } \\
\text { Milder illness - usually self limiting }\end{array}$ & \multirow[t]{2}{*}{ Viral: Enteroviruses, HSV, VZV, mumps, arboviruses, rabies } \\
\hline & $\begin{array}{l}\text { Bacteria: Neisseria meningitides, Streptococcus pneumonia } \\
\text { Less common } \\
\text { Severe illness }\end{array}$ & \\
\hline \multirow[t]{4}{*}{ Spread to CNS } & Haematogenous & \multirow[t]{2}{*}{ From sites of primary infection } \\
\hline & Adjacent focus of infection & \\
\hline & Via bony defect or head injury from nasopharynx & \multirow[t]{2}{*}{ Reactivation } \\
\hline & $\begin{array}{l}\text { Direct implantation via trauma, neurosurgery or other } \\
\text { neurological procedures }\end{array}$ & \\
\hline
\end{tabular}


Table 2. The Cerebral Spinal Fluid (CSF) Findings Supporting a Diagnosis of Viral Meningitis (continued)

\begin{tabular}{|l|l|l|}
\hline \multicolumn{2}{|l|}{ Lumbar Puncture Profile } & \multicolumn{2}{|l|}{ White Blood Cells } & $\begin{array}{l}\text { Bacterial: Raised polymophonucleuocytes - neutrophils } \\
\left(>2000 / \mathrm{mm}^{3}\right)\end{array}$ & $\begin{array}{l}\text { Raised neutrophils early and later raised lymphocytes } \\
\left(<250 / \mathrm{mm}^{3}\right)\end{array}$ \\
\cline { 1 - 2 } & Viral: Raised lymphocytes & \multirow{2}{*}{ Elevated $(<150 \mathrm{mg} / \mathrm{dL})$} \\
\hline Protein Level & Bacterial: Very elevated $(>200 \mathrm{mg} / \mathrm{dL})$ & \\
\cline { 1 - 2 } & Viral: Elevated & Normal $(>50 \%$ blood glucose $)$ \\
\hline \multirow{2}{*}{ Glucose } & Bacterial: Low $(<60 \%$ of blood glucose $)$ & \\
\cline { 2 - 3 } & Viral: Normal $(>50 \%$ blood glucose $)$ & \\
\hline
\end{tabular}

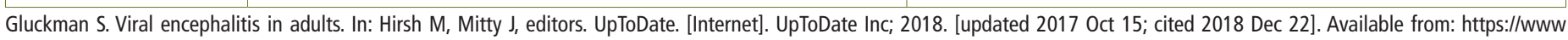
.uptodate.com/contents/viral-encephalitis-in-adults

suspected CNS infections. The delay between hospital admission and acyclovir treatment initiation in viral meningitis beyond two days is a poor prognostic factor and is associated with an increased risk of neurologic sequelae. ${ }^{10} \mathrm{CSF}$ test results will direct subsequent therapy. Antibiotic therapy should be discontinued when bacterial CNS infection has been excluded. VZV meningitis, presenting with or without a preceding rash in immunocompetent hosts is usually benign and self-limited, with recovery in 1 to 2 weeks. ${ }^{3}$ There is controversy over the need for treatment with acyclovir for VZV meningitis in the absence of encephalitis. The Infectious Disease Society of America 2008 clinical practice guidelines recommend treatment of VZV encephalitis with acyclovir based on low-grade evidence.

After consultation with infectious disease specialists and the patient, a joint clinical decision to treat with acyclovir was agreed upon to prevent short- and long-term complications including subtle cognitive impairment, seizures, cerebritis, and a CNS vasculopathy.

The Canadian immunization schedule includes a 2-dose varicella vaccine, which is over $98 \%$ effective in preventing VZV infection. Since its' introduction to the national immunization program in the early 2000s, the incidence of childhood varicella infection, and subsequent VZV related hospitalizations has decreased. ${ }^{9}$ The vaccine is an important public health initiative as it prevents acute chickenpox infection and its complications. The vaccine program reduces hospitalizations, outbreak-related costs and societal costs (missed school and workdays).

There are two vaccines available to prevent herpes zoster, a live vaccine (Zostavax) and a recombinant vaccine (RZV Shingrix). The recombinant vaccine is the preferred vaccine and is recommended for Canadian adults over 50 years old. It may be given to immunosuppressed individuals and has a proven
$70 \%$ reduction of incidence of herpes zoster and post-herpetic neuralgia. ${ }^{10}$

This case of a young healthy male, without viral exanthema, who had confirmed VZV meningitis is extremely rare with only a few cases reported in the literature. ${ }^{7}$ The case emphasizes the importance of testing the CSF broadly for pathogens, including broad-spectrum PCR, in suspected meningitis/encephalitis.

\section{References}

1. Gilden DH, Kleinschmidt-DeMasters BK, LaGuardia JJ, Mahalingam R, Cohrs RJ. Neurologic complications of the reactivation of varicella-zoster virus. N Engl J Med 2000;342:635-45. Available at: https://www.ncbi.nlm.nih. gov/pmc/articles/PMC3139357/ = 1

2. Steiner I, Kennedy PG, Pachner AR. The neurotropic viruses: herpes simples and varicella-zoster virus. Lancet Neurol 2007;6:1015-28.

3. Gnann JW. Varicella-zoster virus, atypical presentations and unusual complications. J Infect Dis 2002;86:S91-8.

4. Galil K, Choo PW, Donahue JG, Platt R. The sequelae of herpes zoster. Arch Intern Med 1997;157:1209.

5. Whitley RJ. Varicella-zoster virus infections. In: Kasper D, Fauci A, Hauser S, Longo D, Jameson J, Loscalzo J. eds. Harrison's Principles of Internal Medicine, $19^{\text {th }}$ edition. New York, NY: McGraw-Hill; 2014. Available at: http://accessmedicine.mhmedical.com.libaccess.lib.mcmaster.ca/content. aspx?bookid $=1130 \&$ sectionid $=79738275$.

6. Gilden D, Cohrs RJ, Mahalingam R, Nagel MA. Varicella zoster virus vasculopathies: diverse clinical manifestations, laboratory features, pathogenesis, and treatment. Lancet Neurol 2009;8(8):731-40.

7. Pasedag T, Weissenborn K, Wurster U, Ganzenmueller T, Stangel M, Skripuletz $\mathrm{T}$. Varicella zoster virus meningitis in a young immunocompetent adult without rash: a misleading clinical presentation. Case Rep Neurol Med 2014;2014.

8. Government of Canada. Varicella (chickenpox) vaccine: Canadian immunization guide; Ottawa: Author; 2018.

9. Government of Canada. Update on the use of herpes zoster vaccine. Ottawa: Author; 2016.

10. Raschilas F, Wolff M, Delatour F, et al. Outcome of and prognostic factors for herpes simplex encephalitis in adult patients: results of a multicenter study. Clin Infect Dis 2002 Aug 1;35(3):254-60. 